\title{
PENGEMBANGAN BEE POLLEN SNACK BAR UNTUK ANAK USIA SEKOLAH
}

\section{[Development of Bee Pollen Snack Bar for School-aged Children]}

\author{
Qurratu Aini ${ }^{1)}$, Ahmad Sulaeman ${ }^{2) \star}$, dan Tiurma Sinaga ${ }^{2)}$ \\ 1) Program Studi IImu Gizi, Sekolah Pascasarjana, Institut Pertanian Bogor, Bogor \\ 2) Departemen Gizi Masyarakat, Fakultas Ekologi Manusia, Institut Pertanian Bogor, Bogor
}

Diterima 28 September 2018 / Disetujui 23 Maret 2020

\begin{abstract}
The objective of this study was to analyze the nutrition content, antioxidant activity, mineral bioavailability and amino acid composition of a bee pollen snack bar. This study was a pure experimental study along with complete randomized design. The treatment factor was the addition of bee pollen which resulted in five formulas. The product was made from Sormeal, rice crispy, chocolates, dates, cashews and bee pollen. Formula F3 with the addition of bee pollen of $10 \%$ was analyzed for its nutrient content, antioxidant activity and availability of $\mathrm{Fe}$ and $\mathrm{Zn}$. The F3 formula contained $5.91 \%$ water, $1.72 \%$ ash, $11.30 \%$ protein, $16.52 \%$ fat and 64.52 carbohydrate. The antioxidant activity test of the product was 10.77 $\mathrm{mg}$ ascorb ic acid/g sample. Meanwhile, the bioavalaibility of Fe and $\mathrm{Zn}$ of the product were 17.02 and 6.84 $\mathrm{mg} / \mathrm{kg}$, respectively. This product can be considered as a nutritious snack that could improve imunity and potentially improve school-aged children learning performance.
\end{abstract}

Keywords: acceptability, antioxidant activity, bee pollen, school-aged children, snack bar

\section{ABSTRAK}

Tujuan dari penelitian ini adalah melakukan analisis terhadap kandungan gizi, aktivitas antioksidan dan bioavailabilitas dari bee pollen snack bar. Penelitian ini merupakan penelitian murni dengan menggunakan desain rancangan acak lengkap. Faktor perlakuan merupakan penambahan bee pollen yang menghasilkan lima formula. Snack bar terbuat dari Sormeal, rice crispy, kurma, kacang mede, madu dan cokelat, bee pollen merupakan faktor yang ditambahkan. Formula F3 dengan penambahan bee pollen sebesar $10 \%$ merupakan formula yang dianalis is kandungan zat gizi, aktivitas antioksidan serta ketersediaan Fe dan Zn. Formula F3 memiliki kandungan kadar air sebesar 5,91\%, abu sebesar 1,72\%, protein sebesar 11,30\%, lemak sebesar 16,52\% dan karbohidrat sebesar 64,52\%. Pada pengujian aktivitas antioksidan diperoleh hasil sebesar $10,77 \mathrm{mg}$ asam askorbat/g sampel. Ketersediaan mineral Fe dan $\mathrm{Zn}$ dari produk berturut-turut adalah 17,02 dan 6,84 mg/kg. Produk ini memenuhi syarat sebagai makanan cemilan yang dapat memberi asupan gizi yang baik, yang dapat meningkatkan imunitas dan berpotensi meningkatkan performa belajar anak usia sekolah.

Kata kunci: aktivitas antioksidan, anak usia sekolah, daya terima, bee pollen, snack bar

\section{PENDAHULUAN}

Asupan zat gizi baik makro maupun mikro berperan sangat penting dalam mendukung pertumbuhan anak, terutama anak usia sekolah. Asupan zat gizi, khususnya zat gizi mikro memiliki peran sangat penting dalam perkembangan otak (Prado dan Dewey, 2014). Kekurangan zat gizi mikro khususnya mineral penting seperti zat besi $(\mathrm{Fe})$ dapat menye-

*Penulis Korespondensi:

E-mail: asulaeman06@gmail.com babkan anemia. Penelitian yang dilakukan oleh Pasricha et al. (2010a) menyatakan anemia yang disebabkan oleh kekurangan zat besi dapat membuat pertumbuhan anak menjadi terhambat. Studi yang dilakukan oleh Pasricha et al. (2010b) pada anak di daerah pedesaan India, menunjukkan bahwa penurunan kadar hemoglobin berhubungan dengan kurangnya asupan vitamin B12 dan asam folat.

Studi menunjukan bahwa anak dengan status zat besi kurang memiliki kemampuan bahasa yang lebih rendah dibandingkan dengan anak dengan status zat besi yang normal (Beltrán-Navarro et al., 
2012). Selain zat besi, seng (Zn) juga berperan penting dalam pertumbuhan anak usia sekolah. Studi yang dilakukan oleh Gibson et al. (2007) menyatakan bahwa kekurangan seng merupakan salah satu faktor yang dapat menyebabkan stunting (balita pendek) pada anak. Penelitian yang dilakukan oleh Compos et al. (2008) menunjukan bahwa bee pollen kaya akan kandungan vitamin dan mineral, diantaranya adalah mineral penting seperti Fe dan $\mathrm{Zn}$. Jumlah zat Fe dan Zn yang terkandung dalam $100 \mathrm{~g}$ bee pollen cukup untuk memenuhi kebutuhan harian anak.

Penelitian yang dilakukan oleh Sandjaja et al. (2013) menunjukan bahwa tingginya persentase anak-anak Indonesia yang belum memenuhi asupan energi dan protein sesuai dengan rekomendasi konsumsi perhari, sehingga anak-anak ini sangat rentan untuk mengalami permasalahan gizi buruk. Komposisi bee pollen mengandung protein dengan kandungan total asam amino yang lebih tinggi dibandingkan dengan kebutuhan protein yang disarankan oleh FAO. Kandungan vitamin dan mineral bee pollen juga tinggi sehingga sangat berpotensi untuk dikembangkan sebagai makanan yang memberikan asupan gizi yang baik untuk perkembangan anak (Yang et al., 2013).

Anak-anak membutuhkan banyak energi untuk aktivitasnya, peran camilan sangat penting dalam memberikan kontribusi energi pada kebutuhan harian anak (Candra et al., 2013). Meskipun tidak terlalu besar, rata-rata kontribusi yang diberikan oleh camilan dalam sehari adalah 20\% (Yasmin dan Madanijah 2010), sehingga pemberian camilan tidak dapat diabaikan agar memaksimalkan kontribusi asupan dalam sehari. Salah satu jenis camilan dengan kandungan padat energi adalah snack bar (Rachmawati et al., 2017). Snack bar yang memiliki sebutan lain yaitu energy bar atau protein bar merupakan sejenis camilan yang padat energi atau protein yang merupakan campuran dari berbagai bahan makanan yang dipadatkan dalam bentuk batang. Umumnya bahan makanan yang digunakan untuk membuat snack bar adalah kacang-kacangan, buahbuahan dan sereal. Pengembangan produk berupa snack bar semakin meningkat, ditandai dengan banyaknya produk komersial snack bar di pasaran dengan label kesehatan yang menyesuaikan kebutuhan konsumen. Salah satu alasan konsumen dalam mengonsumsi snack bar adalah untuk meningkatkan asupan energi dan protein (Mintel, 2013).

Snack bar umumnya terbuat dari bahan-bahan yang memiliki potensi khusus dalam memperbaiki status gizi dan kesehatan. Produk yang dihasilkan oleh lebah sangat banyak dan telah terbukti khasiatnya dalam dunia kesehatan. Bee pollen atau serbuk sari lebah merupakan hasil produk lebah selain propolis dan madu. Bee pollen merupakan sumber dengan kandungan antioksidan yang didominasi oleh polifenol (Fatrcova-Sramkova et al., 2016). Polifenol yang terkandung dalam bee pollen adalah sekitar 3-5\% (Rzepecka-Stojko et al., 2015). Bee pollen merupakan serbuk sari tanaman yang terkumpul di kantong yang terletak di kaki lebah, juga memiliki kandungan gizi yang baik, didalamnya terkandung berbagai macam asam amino yang dibutuhkan lebah untuk bertahan hidup (Attia et al., 2014). Bee pollen memiliki kandungan gizi yang baik, komposisi bee pollen berdasarkan de Arruda et al. (2013) tinggi kandungan protein.

Meskipun telah banyak penelitian mengenai khasiat bee pollen yang sangat baik bagi kesehatan, pengembangan produk menggunakan bee pollen masih jarang dilakukan. Bee pollen telah terbukti aman dikonsumsi sebagai bahan makanan, berdasarkan Estevinho et al. (2011) bee pollen tidak mengandung zat-zat yang dapat membahayakan manusia. Selama ini penelitian pengembangan produk berbahan baku pangan hasil lebah hanya berfokus pada madu dan propolis, padahal potensi bee pollen sebagai bahan baku dalam pengembangan produk sama baiknya dengan propolis dan madu. Menurut Lachman et al. (2010) kualitas dan kuantitas dari bee pollen sama baiknya dengan propolis dan madu dalam memperbaiki status kesehatan.

Proses pembuatan snack bar juga menggunakan sorgum instan sebagai salah satu bahan penyusunnya. Sorgum memiliki banyak keunggulan sebagai pangan sumber karbohidrat. Sorgum memiliki kandungan protein yang lebih tinggi dibandingkan dengan protein yang terkandung dalam beras. Menurut Suani (2012) sorgum memiliki kandungan antioksidan dan asam fenolat serta tidak mengandung gluten. Sorgum instan merupakan langkah divertifikasi pangan pada masyarakat Indonesia yang tergantung pada beras dan gandum (Sakti, 2015). Bee pollen dan sorgum instan yang digunakan sebagai bahan baku dalam pembuatan snack bar merupakan sebuah langkah yang baik dalam menggali lebih jauh potensi dan kandungan gizi dari bee pollen dan sorgum instan, karena belum banyak produk makanan yang menggunakan bahan baku berupa bee pollen dan sorgum instan.

Anak-anak seringkali mengonsumsi camilan atau jajanan yang tidak sehat (Husby et al., 2009). Camilan yang sehat sangat diperlukan untuk membantu anak-anak dalam membuat pilihan jajanan yang lebih baik. Hal ini didukung oleh pernyataan World Health Organization yang menyarankan industri makanan untuk lebih banyak mengembangkan makanan yang sehat dan terjangkau bagi konsumen (WHO, 2004). Pengembangan produk bee pollen snack bar merupakan suatu langkah yang tepat sebagai alternatif camilan anak sekolah sehat yang memiliki kandungan gizi yang baik dan kandungan antioksidan pada anak usia sekolah. 
Penelitian ini bertujuan untuk melakukan pengembangan produk bee pollen snack bar untuk anak usia sekolah. Penelitian juga bertujuan untuk membuat formula bee pollen snack bar, melakukan uji organoleptik yang meliputi uji hedonik dan mutu hedonik dari bee pollen snack bar, kandungan gizi, dan aktivitas antioksidan yang terkandung dalam bee pollen snack bar serta mengetahui daya terima snack bar bee pollen pada anak usia sekolah.

\section{BAHAN DAN METODE}

\section{Bahan}

Bahan-bahan yang digunakan untuk membuat snack bar antara lain sorgum instan, rice crispy, cokelat, kacang mede, kurma, madu dan bee pollen. Bee pollen yang digunakan dalam pembuatan snack bar merupakan bee pollen dari lebah jenis Trigona Sp. yang diperoleh dari Pusat Pengembangan Hasil Hutan Pematang Siantar.

\section{Proses pembuatan snack bar}

Bahan-bahan yang digunakan dalam pembuatan snack bar terdiri dari bahan-bahan kering dan bahan basah. Bahan kering antara lain sorgum instan, rice crispy, kacang mede dan bee pollen. Sorgum instan memiliki tekstur yang sangat kering dan sangat susah untuk dikunyah sehingga harus disangrai terlebih dahulu agar tekstur sorgum instant berubah menjadi renyah dan mudah untuk dikunyah. Sorgum instan disangrai dengan menggunakan api kecil sampai berubah warna menjadi kecokelatan, sampai tekstur menjadi lebih renyah. Kacang mede dipanggang di dalam oven (Mahyih MT 735, Japan) dengan suhu $100^{\circ} \mathrm{C}$ selama 30 menit, setelah dipanggang dicincang kasar. Sorgum instan yang telah disangrai dan kacang mede yang telah dicincang, dicampurkan dengan rice crispy lalu diaduk merata. Bee pollen diayak agar tidak ada yang menggumpal. Bee pollen yang sudah diayak, dicampurkan ke dalam adonan sorgum instan, kacang mede dan rice crispy.

Bahan Basah terdiri dari kurma, madu dan cokelat. Kurma dihaluskan dengan menggunakan food processor (Cosmos FP300, Indonesia). Kurma yang sudah dihaluskan dan madu dicampurkan ke dalam adonan kering, lalu diaduk sampai rata. Selanjutnya, cokelat dilelehkan dengan cara ditim di atas air mendidih. Cokelat leleh dituang ke dalam adonan, kemudian diaduk sampai merata. Setelah semua adonan tercampur merata, adonan dicetak dengan menggunakan cetakan batang yang berukuran $12 \times 2 \times 0,75 \mathrm{~cm}$. Adonan yang sudah dicetak disimpan di dalam lemari pendingin selama satu jam. Adonan yang sudah mengeras, dikeluarkan dari cetakan, kemudian dikemas menggunakan plastik bening.

\section{Uji organoleptik}

Setelah membuat snack bar, dilakukan uji organoleptik pada 30 orang panelis semi terlatih yang merupakan mahasiswa S1 dan pascasarjana departemen gizi masyarakat IPB yang pernah mengikuti pelatihan organoleptik sebelumnya. Uji organoleptik yang dilakukan terdiri dari uji hedonik dan uji mutu hedonik, uji organoleptik dilakukan untuk mengetahui penerimaan produk serta untuk memilih formula terpilih. Uji hedonik yang dilakukan meliputi atribut warna, rasa, aroma, tekstur, aftertaste (rasa yang masih melekat) dan keseluruhan. Uji mutu hedonik terdiri dari atribut warna, aroma bee pollen, aroma cokelat, rasa manis, rasa kurma, rasa asam, tekstur dan aftertaste. Panelis diberikan 5 snack bar dengan formula yang berbeda. Uji organoleptik ditujukan untuk mengetahui respon panelis terhadap penambahan bee pollen pada produk snack bar. Panelis diberikan waktu untuk mengisi kuesioner yang berisi tentang tanggapan terhadap produk.

\section{Analisis kadar air metode oven (AOAC, 2006)}

Metode ini menggunakan metode pengeringan dengan menggunakan (Memmert UN 55, Jerman) desikator dan cawan alumunium. Cawan alumunium ditimbang beratnya setelah dikeringkan terlebih dahulu dalam oven selama 15 menit dan didinginkan selama satu jam dalam desikator.Sampel ditimbang dengan berat sebesar $1 \mathrm{~g}$. Suhu oven diatur pada suhu $105^{\circ} \mathrm{C}$, kemudian cawan berisi sampel dimasukan ke dalam oven selama 8 jam. Setelah 8 jam, cawan alumunium dikeluarkan dari oven, didinginkan dalam desikator selama satu jam, lalu ditimbang. Rumus perhitungan kadar air adalah sebagai berikut:

Kadar Air $(\%)=\frac{\text { bobot sampel }(\text { segar-kering })}{\text { bobot sampel segar }} \times 100 \% \ldots$

\section{Analisis kadar abu (AOAC, 2006)}

Cawan yang digunakan pada analisis kadar abu adalah cawan porselen. Cawan yang digunakan ditandai terlebih dahulu bagian bawah cawan, penandaan ini dimaksudkan agar cawan tidak tertukar satu sama lain, cawan harus ditandai dengan menggunakan pensil karena tinta pulpen atau spidol akan mudah luntur pada pemanasan tingkat tinggi. Cawan yang sudah ditandai dikeringkan dalam tanus pada suhu $600^{\circ} \mathrm{C}$ selama 15 menit, lalu didinginkan dalam desikator selama satu sampai dua jam. Cawan yang sudah dingin diisi dengan sampel dengan berat $3 \mathrm{~g}$. Cawan yang berisi sampel dibakar terlebih dahulu diatas kompor sampai tidak berasap. Selanjutnya, cawan berisi sampel dimasukan kedalam tanur dengan suhu sebesar $600^{\circ} \mathrm{C}$ selama 6 jam. Cawan dikeluarkan dan didinginkan dalam desikator selama satu sampai dua jam. Cawan yang sudah 
dingin ditimbang beratnya. Rumus perhitungan kadar abu adalah sebagai berikut:

Kadar Abu (\%) $=\frac{\text { berat abu }}{\text { berat sampel }} \times 100 \%$.

Berat abu adalah berat cawan setelah diabukan dikurangi berat cawan kosong. Berat sampel yang dihitung adalah berat sebelum diabukan.

\section{Analisis protein mikro kjehdahl (AOAC, 2006)}

Sampel ditimbang dengan berat sebesar 0,25 g. Sampel kemudian dimasukan ke dalam labu kjehdahl $200 \mathrm{~mL}$. Sampel dalam labu kjehdahl dicampur dengan $0,25 \mathrm{~g}$ selenium mix, lalu ditambahkan dengan $3 \mathrm{~mL} \mathrm{H}_{2} \mathrm{SO}_{4}$ pekat dalam ruang asam. Sampel kemudian didekstruksi di atas kompor di dalam ruang asam selama satu jam atau sampai larutan menjadi jernih. Larutan didinginkan dan diencerkan dengan menggunakan akuades sampai dalam labu ukur $50 \mathrm{~mL}$. Larutan dipindahkan ke dalam labu destilasi dan ditambahkan $\mathrm{NaOH} 40 \%$ sebanyak 20 $\mathrm{mL}$. Hasil destilasi ditampung dalam wadah labu erlenmeyer berisi $10 \mathrm{~mL}$ H3BO3 2\% dan 2 tetes indikator Brom Cresol Green-Methyl Red, Iarutan menjadi berwarna merah muda setelah ditetesi dengan indikator Brom Cresol Green-Methyl Red. Destilasi dihentikan setelah warna larutan di wadah penampungan hasil destilasi berubah menjadi hijau kebiruan. Hasil destilasi kemudian dititrasi dengan menggunakan $\mathrm{HCl} 0,1 \mathrm{~N}$ sampai berubah warna menjadi merah muda. Kadar nitrogen dalam sampel dihitung dengan menggunakan rumus sebagai berikut:

Kadar Protein $(\%)=\frac{\text { vol. } \text { titrasi } \times \mathrm{NHCl} \times 14 \times 100 \%}{\mathrm{mg} \mathrm{sampel}} \times 6,25$.

\section{Kadar lemak metode soxhlet (AOAC, 2006)}

Labu lemak dikeringkan dalam oven selama 1-2 jam pada suhu $105^{\circ} \mathrm{C}$. Labu lemak yang telah kering, diletakan pada desikator sampai dingin, lalu beratnya ditimbang. Sampel dengan berat $5 \mathrm{~g}$ dibungkus dan diikat dalam kertas saring. Sampel dimasukkan dalam soxhlet, labu lemak diletakan dibawah alat ekstraksi soxhlet. Labu lemak diisi dengan pelarut hexane, dipanaskan agar pelarut hexane naik melewati kondensor dan turun kembali ke dalam labu lemak, proses ini berlangsung selama kurang lebih 6 jam bergantung pada kandungan lemak dalam sampel. Setelah melalui proses ekstraksi, labu lemak dikeringkan kembali dalam oven selama 1 jam pada suhu $105^{\circ} \mathrm{C}$ agar sisa pelarut hexane menguap dengan sempurna. Labu lemak kemudian didinginkan dalam desikator, lalu timbang beratnya. Rumus untuk menghitung kandungan lemak adalah sebagai berikut:
Kadar Lemak $(\%)=\frac{\text { berat lemak }}{\text { bobot sampel }}$

Berat lemak adalah bobot labu lemak setelah ekstraksi dikurangi bobot labu lemak kosong.

\section{Kadar karbohidrat dengan by different}

Kadar karbohidrat tidak dianalisis dengan prosedur laboratorium, melainkan dihitung dengan menggunakan metode by different. Metode by different merupakan metode pengurangan dari penjumlahan yang diperoleh pada analisis kadar air, kadar abu, kandungan protein dan kandungan lemak dalam sampel. Rumus yang digunakan untuk menghitung kandungan karbohidrat dengan metode by different adalah sebagai berikut: Kadar Karbohidrat $(\%)=100 \%$ (\% kadar air+\% kadar abu+\% protein+ $\%$ lemak).

\section{Kandungan energi}

Kandungan total energi dari produk diperoleh dari hasil konversi kandungan protein, lemak dan karbohidrat. Kandungan protein dikalikan 4 kal, kandungan lemak dikalikan 9 kal dan kandungan karbohidrat dikalikan dengan $4 \mathrm{kal}$.

\section{Aktivitas antioksidan snack bar}

Aktivitas antioksidan pada bee pollen snack bar dilakukan dengan menggunakan metode DPPH, DPPH merupakan singkatan dari senyawa kimia organik 1.1-diphenyl-2-pycryhydrazil. DPPH merupakan metode pengujian antioksidan yang dinyatakan dalam ascorbic acic equivalent antioxidant capacity (AEAC). Aktivitas antioksidan ditunjukan oleh besarnya selisih absorbansi dibandingkan dengan kontrol.

Tahap analisis aktivitas antioksidan diawali dengan penimbangan sampel.Sampel basah dikeringkan selama 48-96 jam, setelah kering sampel dihaluskan sampai menjadi serbuk dengan menggunakan blender (Philips HR2116, Belanda). Tahapan selanjutnya adalah ekstraksi sampel dengan meserasi (Anwar et al., 2013). Ekstraksi sampel menggunakan sampel sebanyak $1 \mathrm{~g}$, sampel dicampurkan dengan $25 \mathrm{~mL}$ methanol dalam Erlenmeyer $125 \mathrm{~mL}$ selama 1×24 jam menggunakan shaker. Setelah sampel tercampur dengan methanol, dilakukan tahapan ekstraksi bertahap sampai diperoleh filtrat yang berwarna bening. Filtrat yang berwarna bening kemudian diuapkan dengan menggunakan evaporator. Ekstrak lalu dilarutkan kembali dalam larutan metanol 5-20 mL.

Tahapan selanjutnya dari analisis aktivitas antioksidan adalah menentukan aktivitas penangkal radikal bebas dengan menggunakan DPPH (1.1diphenyil-2pycrylhydrazyl-radical-scavenging). Ekstrak dari sampel dengan deret volume 20, 40, 80 , $120,200,300,400$, dan $500 \mu \mathrm{L}$ ditingkatkan volume- 
nya sampai mencapai volume $1 \mathrm{~mL}$ dengan menggunakan air bebas ion, kemudian dikocok dengan menggunakan vortex sampai homogen, masingmasing ekstrak ditambahkan $1 \mathrm{~mL}$ larutan DPPH 0,5 $\mathrm{mM}$, lalu dikocok dengan menggunakan vortex. Selanjutnya, ditambahkan dengan $3 \mathrm{~mL}$ air bebas ion, kemudian dicampurkan sampai homogen dengan menggunakan vortex. Larutan yang sudah tercampur, disentrifugasi dengan kecepatan 3500 rpm selama 10 menit. Tiga puluh menit setelah ditambahkan DPPH, larutan yang sudah disentrifugasi dibaca serapan gelom-bangnya pada $\lambda=517 \mathrm{~nm}$.

Analisis kapasitas antioksidan dengan kesetaraan vitamin C (asam askorbat) merupakan tahapan terakhir. Pada tahap ini, larutan penyangga asetat $100 \mathrm{nM}$ dengan $\mathrm{pH}$ 5,5 sebanyak 1,5 mL dicampurkan dengan $2,85 \mathrm{~mL}$ metanol p.a, $1 \mathrm{~mL}$ DPPH dan 0,020 $\mathrm{mL}$ ekstrak metanol dalam tabung reaksi. Campuran dari larutan itu kemudian dibaca absorbansinya pada $\lambda=517 \mathrm{~nm}, 20$ menit setelah DPPH ditambahkan. Kesetaraan kapasitas antioksidan dengan vitamin $\mathrm{C}$ dinyatakan dalam ascorbic acid equivalent antioxidant capacity (AEAC), yang dihitung dengan menggunakan persamaan sebagai berikut:

$$
\mathrm{mg} \mathrm{AEAC} / 100 \mathrm{~g}=\frac{\frac{\text { \%aktivitas antioksidan }}{\mathrm{a}} \times \mathrm{f} \mathrm{p}}{1000} \times \frac{100}{\text { berat sampel }} \ldots
$$

\section{Daya terima bee pollen snack bar pada anak usia sekolah}

Uji daya terima terhadap rasa dari bee pollen snack bar dilakukan pada anak usia sekolah setelah mengetahui analisis kandungan gizi dan kandungan antioksidan dari snack bar. Daya terima pada anak usia sekolah dilakukan pada SDN 01 Dramaga pada 30 orang siswa dengan kisaran umur 9-10 tahun. Siswa dipilih berdasarkan pertimbangan guru dan sekolah, sehingga tidak mengganggu aktivitas belajar mengajar siswa.

Daya terima produk bee pollen snack bar pada anak usia sekolah dilakukan dengan menggunakan facial hedonic scale, yang mana lebih memberikan hasil yang akurat ketika menggunakan subjek anakanak pada uji penerimaan. Penilaian dengan menggunakan facial hedonic scale lebih memberikan hasi yang akurat ketika menggunakan subjek anak-anak (Aaron et al., 2011). Facial hedonic scale yang dilakukan adalah uji penerimaan terhadap rasa dari produk. Pada saat pelaksanaan daya terima, anak-anak duduk di kursi dan bangku yang terpisah dari temantemannya, untuk mengurangi saling diskusi antara siswa. Anak-anak usia sekolah mudah sekali terpengaruh teman sebayanya, sehingga harus dipisahkan dari teman lainnya.

\section{Analisis data}

Analisis statistik dilakukan dengan menggunakan microsoft excel 2010 dan statistical package for the social sciences (SPSS) 16.0 for windows. Analisis ini diperuntukan untuk mengetahui pengaruh perlakukan dan tingkat kesukaan panelis terhadap formula produk. Data hasil organoleptik dianalisis dengan menggunakan uji Kruskal Wallis yang dilanjutkan dengan melakukan uji beda menggunakan prosedur Dunn.

\section{HASIL DAN PEMBAHASAN}

\section{Penentuan formulasi bee pollen snack bar}

Formula snack bar ditetapkan dengan melakukan tahapan percobaan. Tahapan percobaan bertujuan untuk memperoleh keseimbangan proporsi bahan-bahan, khususnya bee pollen. Rancangan formula ditunjukkan untuk mengetahui proporsi penambahan bee pollen yang dapat diterima secara organoleptik. Terdapat lima formula dengan proporsi penambahan bee pollen yang berbeda. Kelima formula tersebut adalah FO (kontrol) yaitu formula snack bar tanpa penambahan bee pollen, F1 yaitu formula dengan penambahan bee pollen sebesar $3 \%$, F2 merupakan formula dengan penambahan $5 \%$ bee pollen, F3 merupakan formula dengan penambahan $10 \%$ bee pollen dan F4 adalah formula dengan penambahan $15 \%$ bee pollen. Persentase penambahan bee pollen pada formula F0 sampai F4 dibuat semakin besar untuk mengidentifikasi umpan balik penam-bahan bee pollen pada snack bar yang diuji pada tahapan selanjutnya yaitu uji organoleptik. Bahan dan jumlah bahan yang digunakan dalam proses pembuatan snack bar dapat dilihat pada Tabel 1.

Tabel 1. Formulasi bee pollen snack bar

\begin{tabular}{lccccc}
\hline \multicolumn{1}{c}{ Bahan } & F0 & F1 & F2 & F3 & F4 \\
\hline Sorgum instan $(\mathrm{g})$ & 15 & 15 & 15 & 15 & 15 \\
Rice crispy $(\mathrm{g})$ & 20 & 20 & 20 & 20 & 20 \\
Cokelat $(\mathrm{g})$ & 30 & 30 & 30 & 30 & 30 \\
Madu $(\mathrm{g})$ & 10 & 10 & 10 & 10 & 10 \\
Kurma $(\mathrm{g})$ & 20 & 20 & 20 & 20 & 20 \\
Kacang mede & 25 & 25 & 25 & 25 & 25 \\
Bee pollen $(\mathrm{g})$ & 0 & 3 & 5 & 10 & 15 \\
\hline
\end{tabular}

\section{Uji organoleptik}

Hasil dari uji hedonik dan uji mutu hedonik tersedia pada Tabel 1 dan Tabel 2. Kuesioner berisi skala penilaian terhadap produk. Skala yang digunakan adalah skala garis dengan rentang nilai antara 1 sampai dengan 9. Berdasarkan uji Kruskal Wallis pada atribut warna pada uji hedonik, snack bar F2 dan F3 memperoleh nilai tertinggi pada atribut warna, sedangkan snack bar FO memperoleh nilai terendah. 
Warna merupakan atribut sensori yang paling cepat memberikan kesan karena dapat diterima dan dilihat langsung oleh panelis (Winarno, 2009). Berdasarkan Tabel hasil uji mutu hedonik, penilaian warna F0 atau kontrol berada pada angka 5,47 yang berarti panelis mengartikan warna snack bar adalah warna kuning gelap. Penambahan bee pollen pada produk meningkatkan derajat kecerahan pada produk, sehingga panelis lebih menyukai warna produk dengan penambahan bee pollen.

Hasil yang diperoleh pada uji hedonik atribut rasa berkisar pada angka 3,79-6,78. Formula F0 yang merupakan formula kontrol memperoleh nilai tertinggi, sementara itu formula F4 memperoleh nilai terendah. Rasa merupakan atribut penilaian yang berhubungan dengan indera pengecap. Penambahan bee pollen pada snack bar secara signifikan menurunkan tingkat kesukaan panelis pada atribut rasa. Rasa dari bee pollen sangat asam, sehingga semakin banyak bee pollen yang ditambahkan, maka rasa dari snack bar semakin asam.

Penilaian mutu hedonik pada atribut rasa terbagi menjadi tiga penilaian, yaitu rasa asam, rasa kurma dan rasa manis. Rasa manis pada snack bar berasal dari madu, cokelat dan kurma, sementara itu rasa asam berasal dari kurma dan bee pollen, atribut rasa kurma ditambahkan untuk memberikan informasi yang lebih jelas mengenai rasa dari snack bar. Formula F2 merupakan formula yang memperoleh nilai tertinggi pada atribut rasa manis dengan skor 5,84, sementara itu formula F4 memperoleh nilai terendah dengan skor 4,78. Berdasarkan uji lanjut Dunn, Penilaian rasa manis tidak berbeda nyata pada semua formula, kecuali pada formula F4.

Hasil yang diperoleh pada atribut rasa kurma, formula F3 memperoleh nilai tertinggi dengan skor 5,80 , sementara formula F0 memperoleh nilai terendah dengan skor 4,01. Formula F0 berbeda nyata dengan formula lainnya. Kurma yang digunakan pada setiap formula memiliki berat yang sama, akan tetapi respon penilaian panelis pada rasa kurma berbeda-beda, diduga faktor penambahan bee pollen memengaruhi penilaian panelis terhadap rasa kurma pada snack bar.

Penilaian mutu hedonik pada atribut rasa asam pada snack bar berkisar pada nilai 2,44-7,33 (sangat tidak asam-asam). Nilai tertinggi adalah formula F4 yaitu 7,33 (asam), sementara perolehan nilai terendah adalah F0 (kontrol) yaitu 2,44 (sangat tidak asam). Penilaian mutu hedonik terhadap rasa asam dari snack bar menunjukan bahwa semakin banyak penambahan bee pollen dalam snack bar maka semakin asam rasa dari snack bar.

Hasil uji hedonik pada atribut aroma dari snack bar adalah 6,63-4,84. Penilaian mutu hedonik aroma pada snack bar terbagi menjadi dua, yaitu aroma cokelat dan aroma bee pollen. Pada penilaian uji mutu hedonik, aroma cokelat pada formula FO memperoleh hasil tertinggi yaitu 6,09 , Formula F4 memperoleh skor terendah yaitu 4,47. Skor aroma bee pollen pada formula F0 yang merupakan formula kontrol tanpa penambahan bee pollen adalah 2,87 (sangat lemah), sebaliknya skor aroma bee pollen pada Formula F4 adalah 6,01. Hasil yang diperoleh pada penilaian uji mutu hedonik pada atribut aroma memperlihatkan bahwa aroma bee pollen menutupi aroma cokelat yang terdapat pada produk.

Hasil yang diperoleh dari penilaian uji hedonik terhadap tekstur snack bar berkisar pada angka 4,47-5,87. Hasil perolehan tertinggi merupakan formula F3 yaitu 5,87 , formula dengan perolehan terendah adalah formula F0 yaitu 4,47. Faktor penambahan bee pollen pada setiap formula tidak memberikan perubahan nyata pada tekstur. Perolehan skor tertinggi pada atribut tekstur adalah formula F3, perolehan skor terendah adalah formula kontrol yang merupakan formula tanpa penambahan bee pollen, sehingga dengan kata lain penambahan bee pollen meningkatkan kualitas penerimaan tekstur dari snack bar.

Hasil yang diperoleh dari uji hedonik aftertaste dari snack bar berkisar pada nilai 4,15-6,43 (agak tidak suka-agak suka). Formula yang memperoleh skor tertinggi pada atribut aftertaste (rasa yang masih melekat) adalah formula F0 yaitu 6,43, sementara itu formula dengan skor terendah adalah formula F4 yaitu 4,15, hal ini berarti panelis agak tidak menyukai formula F4. Penambahan bee pollen meningkatkan aftertaste pada uji hedonik dari snack bar. Hasil memperlihatkan bahwa semakin banyak penambahan bee pollen maka aftertaste snack bar semakin kuat.

Tabel 2. Hasil uji hedonik bee pollen snack bar

\begin{tabular}{ccccccc}
\hline \multirow{2}{*}{ Formula } & \multicolumn{5}{c}{ Atribut } \\
\cline { 2 - 6 } & Warna & Rasa & Aroma & Tekstur & Aftertaste & Keseluruhan \\
\hline F0 & $5,24^{\mathrm{a}}$ & $6,78^{\mathrm{D}}$ & $6,63^{\mathrm{D}}$ & $4,47^{\mathrm{a}}$ & $6,43^{\mathrm{c}}$ & $6,18^{\mathrm{D}}$ \\
F1 & $5,49^{\mathrm{ad}}$ & $6,14^{\mathrm{D}}$ & $6,17^{\mathrm{D}}$ & $5,03^{\mathrm{a}}$ & $6,04^{\mathrm{DC}}$ & $6,28^{\mathrm{D}}$ \\
F2 & $5,93^{\mathrm{D}}$ & $6,19^{\mathrm{D}}$ & $6,24^{\mathrm{D}}$ & $5,77^{\mathrm{D}}$ & $5,61^{\mathrm{D}}$ & $6,17^{\mathrm{D}}$ \\
F3 & $5,93^{\mathrm{D}}$ & $4,80^{\mathrm{a}}$ & $5,50^{\mathrm{a}}$ & $5,87^{\mathrm{D}}$ & $4,72^{\mathrm{a}}$ & $5,10^{\mathrm{a}}$ \\
F4 & $5,25^{\mathrm{a}}$ & $3,79^{\mathrm{a}}$ & $4,84^{\mathrm{a}}$ & $5,35^{\mathrm{ab}}$ & $4,15^{\mathrm{a}}$ & $4,64^{\mathrm{a}}$ \\
\hline
\end{tabular}

Keterangan: Skala atribut, yaitu 1 = amat sangat tidak suka hingga 9 = amat sangat suka; Huruf yang berbeda pada

kolom yang sama menyatakan bahwa hasil berbeda nyata $(P<0,05)$ 


\section{Penentuan formula terpilih}

Berdasarkan hasil uji statistik menggunakan uji Kruskal Wallis dan dilanjutkan dengan uji lanjut Dunn, formula terpilih merupakan formula F2. Formula F2 merupakan formula snack bar dengan penambahan $5 \%$ bee pollen, secara uji organoleptik formula ini merupakan formula terbaik, akan tetapi faktor penambahan $5 \%$ bee pollen pada snack bar tidak cukup untuk memenuhi rekomendasi konsumsi bee pollen per hari sebagai penunjang kesehatan tubuh. Jumlah bee pollen yang ditambahkan pada formula F2 adalah $5 \mathrm{~g}$. Berdasarkan penelitian yang dilakukan oleh Nagai et al. (2007), rekomendasi konsumsi bee pollen untuk memenuhi kebutuhan asam amino per hari adalah sebesar $15 \mathrm{~g}$. Berdasarkan pertimbangan rekomendasi konsumsi bee pollen per hari maka Formula F2 tidak sesuai dengan kriteria tersebut.

Formula F4 yang merupakan formula snack bar dengan penambahan $15 \%$ bee pollen, jumlah bee pollen yang ditambahkan pada formula ini adalah 15 gram. Formula F4 merupakan formula yang memenuhi saran konsumsi bee pollen per hari, namun secara organoleptik formula F4 merupakan formula dengan penerimaan terendah, sehingga Formula F3 yang merupakan formula dengan penambahan $10 \%$ bee pollen yang dipertimbangkan sebagai formula terpilih. Formula F3 terpilih sebagai formula snack bar yang dianalisis kandungan gizi, aktivitas antioksidan dan komposisi asam amino pada tahapan penelitian selanjutnya.

\section{Kadar air}

Kandungan air merupakan komponen yang penting dalam suatu bahan makanan, keberadaan air dalam suatu bahan pangan dapat mempengaruhi daya simpan, tekstur, cita rasa dan penampakan dari produk (Winarno, 2008). Berdasarkan Tabel 3, kadar air yang dimiliki oleh bee pollen snack bar adalah sebesar $5,91 \%$ yang mana melampaui angka maksimal kadar air berdasarkan syarat mutu kue kering (cookies) (BSN, 2011) yaitu sebesar 5\%. Tingginya kadar air dalam produk disebabkan oleh proses pembuatan produk tanpa menggunakan panas, sehingga tidak mengurangi kandungan kadar air yang terdapat pada bahan-bahan yang digunakan untuk membuat produk.

\section{Kadar abu}

Kandungan mineral dalam suatu bahan pangan dapat ditunjukan oleh hasil analisis kadar abu. Kadar abu selain menjadi parameter untuk mengetahui kandungan mineral dalam bahan pangan, juga merupakan penanda adanya cemaran logam pada suatu bahan makanan. Hasil analisis kadar abu dari produk adalah 1,72\%. Angka maksimal kadar abu kue kering (cookies) menurut SNI uji Makanan dan Minuman adalah 2\% (BSN, 2011). Kadar abu dari bee pollen snack bar sudah memenuhi syarat karena tidak melampaui angka maksimal kadar abu berdasarkan syarat mutu SNI.

\section{Kadar protein}

Protein merupakan salah satu zat gizi yang penting bagi tubuh, fungsinya sebagai sumber penghasil energi, zat pembangun dan pengatur. Protein sangat berguna untuk pertumbuhan anak usia sekolah. Kandungan protein dalam snack bar tergolong tinggi karena melebihi standar dari syarat mutu SNI kue kering (cookies). Protein dari kue kering minimal 5\% (BSN, 2011), sementara itu kandungan protein dari bee pollen snack bar adalah $11,3 \%$. Kandungan protein yang tinggi berasal dari bahanbahan yang digunakan dalam proses pembuatan snack bar, salah satunya bee pollen. Snack bar telah memenuhi syarat dalam pemenuhan protein berdasarkan standar SNI kue kering, sehingga sangat baik untuk dikonsumsi sebagai cemilan anak usia sekolah.

Tabel 3. Hasil uji mutu hedonik snack bar bee pollen

\begin{tabular}{ccccccccc}
\hline \multirow{2}{*}{ Formula } & \multicolumn{7}{c}{ Atribut } \\
\cline { 2 - 9 } & Warna & $\begin{array}{c}\text { Aroma Bee } \\
\text { Pollen }\end{array}$ & $\begin{array}{c}\text { Aroma } \\
\text { Cokelat }\end{array}$ & $\begin{array}{c}\text { Rasa } \\
\text { Manis }\end{array}$ & $\begin{array}{c}\text { Rasa } \\
\text { Kurma }\end{array}$ & $\begin{array}{c}\text { Rasa } \\
\text { Asam }\end{array}$ & Tekstur & Aftertaste \\
\hline F0 & $5,47^{\mathrm{a}}$ & $2,87^{\mathrm{a}}$ & $6,09^{\mathrm{D}}$ & $5,79^{\mathrm{D}}$ & $4,01^{\mathrm{a}}$ & $2,44^{\mathrm{a}}$ & $5,61^{\mathrm{a}}$ & $3,44^{\mathrm{a}}$ \\
F1 & $7,40^{\mathrm{DC}}$ & $3,67^{\mathrm{ab}}$ & $6,00^{\mathrm{D}}$ & $5,79^{\mathrm{D}}$ & $4,98^{\mathrm{D}}$ & $3,45^{\mathrm{a}}$ & $5,99^{\mathrm{a}}$ & $4,09^{\mathrm{ab}}$ \\
F2 & $7,75^{\mathrm{c}}$ & $3,88^{\mathrm{D}}$ & $5,76^{\mathrm{D}}$ & $5,84^{\mathrm{D}}$ & $5,21^{\mathrm{DC}}$ & $4,95^{\mathrm{D}}$ & $6,05^{\mathrm{a}}$ & $4,81^{\mathrm{D}}$ \\
F3 & $7,70^{\mathrm{C}}$ & $5,35^{\mathrm{c}}$ & $5,01^{\mathrm{a}}$ & $5,33^{\mathrm{ad}}$ & $5,80^{\mathrm{c}}$ & $6,61^{\mathrm{c}}$ & $6,19^{\mathrm{a}}$ & $5,78^{\mathrm{c}}$ \\
F4 & $6,89^{\mathrm{ab}}$ & $6,01^{\mathrm{c}}$ & $4,47^{\mathrm{a}}$ & $4,78^{\mathrm{a}}$ & $5,37^{\mathrm{c}}$ & $7,33^{\mathrm{c}}$ & $5,87^{\mathrm{a}}$ & $6,21^{\mathrm{c}}$ \\
\hline
\end{tabular}

Keterangan: Atribut warna skala $1=$ krem cerah hingga $9=$ cokelat gelap, atribut aroma bee pollen skala $1=$ amat sangat lemah hingga 9 = amat sangat kuat, atribut aroma cokelat skala $1=$ amat sangat lemah hingga $9=$ amat sangat kuat, atribut rasa manis skala 1 = tidak manis sama sekali hingga $9=$ amat sangat manis, atribut rasa kurma skala 1 = tidak berasa sama sekali hingga 9 = amat sangat berasa, atribut rasa asam skala 1 = tidak asam sama sekali hingga 9 = amat sangat as am, atribut tekstur skala 1 = amat sangat keras hingga amat sangat renyah, atribut aftertaste skala 1 = amat sangat lemah hingga $9=$ amat sangat kuat; Huruf yang berbeda pada kolom yang sama menyatakan bahwa hasil berbeda nyata: $(P<0,05)$ 


\section{Kadar lemak}

Kandungan lemak snack bar berdasarkan hasil analisis adalah sebesar $16,52 \%$. Minimal kandungan lemak dari snack bar berdasarkan syarat mutu dari kue kering (cookies) (BSN, 2011) adalah sebesar $9,5 \%$. Lemak yang terkandung pada bee pollen snack bar melebihi syarat dari kandungan lemak kue kering SNI 01-2973-1992. Kandungan lemak yang tinggi pada snack bar berasal dari bahan makanan yang memiliki kandungan lemak baik, salah satunya adalah kacang mede.

Konsumsi kacang-kacangan pada anak usia sekolah sangat penting karena kacang-kacangan merupakan sumber dari protein nabati dan lemak tak jenuh yang baik bagi tubuh (Grosso dan Estruch, 2015). Jenis kacang-kacangan yang digunakan dalam pembuatan snack bar adalah kacang mede. Kacang mede memiliki kandungan asam lemak tak jenuh yang tinggi, protein yang tinggi serta kaya akan berbagai macam jenis antioksidan yang dapat mencegah terjadinya penyakit sindrom metabolik (Mah et al., 2017).

Tabel 4. Hasil analisis kandungan gizi bee pollen snack bar

\begin{tabular}{lccc}
\hline Kandungan Gizi & Unit & Hasil & SNI $^{*}$ \\
\hline Air & $(\%$ bk) & 5,91 & Maks.5 \\
Abu & $(\%$ bk) & 1,72 & Maks.2 \\
Protein & $(\%$ bk) & 11,30 & Min. 5 \\
Lemak & $(\%$ bk) & 16,52 & Min. 9.5 \\
Karbohidrat & $(\%$ bk) & 64,52 & Min. 70 \\
Total Energi & kkal 100g & 451,96 & \\
Keterangan: ${ }^{*}$ SNI Uji Makanan dan Minuman (BSN, 2011)
\end{tabular}

\section{Karbohidrat}

Kandungan karbohidrat dalam bahan pangan berfungsi dalam memperbaiki tekstur, warna dan rasa dari suatu bahan makanan (Winarno, 2008). Kandungan karbohidrat bee pollen snack bar hasil analisis adalah sebesar $64,52 \%$, hasil ini berada dibawah syarat mutu kue kering (cookies) (SNI: No 01-2973-1992) yaitu minimal 70\%. Kandungan karbohidrat diperoleh dari hasil perhitungan by difference, kandungan karbohidrat rendah karena persentase kandungan gizi lain yang tinggi dalam bahan pangan (Kustyawati, 2012).

\section{Kandungan energi}

Berdasarkan hasil konversi dari kandungan protein, lemak dan karhohidrat, kandungan energi dari $100 \mathrm{~g}$ snack bar adalah sebesar 451,96 kkal $100 \mathrm{~g}^{-1}$. Berat snack bar per sajiannya adalah $25 \mathrm{~g}$, dengan jumlah kalori dalam satu sajiannya adalah 113 kkal. Rata-rata kontribusi per hari yang diberikan oleh makanan selingan adalah 20\% (Yasmin dan Madanijah 2010), sehingga jumlah energi yang harus dipenuhi dari makanan selingan untuk kebutuhan anak usia 7-9 tahun adalah 370 kkal. Satu anak harus mengonsumsi tiga sajian snack bar per hari untuk memenuhi kebutuhan energi selingan.

\section{Aktivitas antioksidan bee pollen snack bar}

Penambahan bee pollen pada snack bar ditujukan untuk meningkatkan status kesehatan anak dengan meningkatkan daya tahan tubuh, menurut Campos et al. (2010), bee pollen berfungsi dalam menyembuhkan penyakit dan memiliki nilai gizi yang baik. Khasiat bee pollen dalam menyembuhkan penyakit tidak terlepas dari kandungan vitamin dan mineral yang sangat kaya di dalamnya, kandungan Vitamin $C$, E dan $\beta$-karoten yang merupakan senyawa antioksidan cukup mendominasi dalam komposisinya (Campos et al., 2010).

Hasil analisis dari aktivitas antioksidan bee pollen snack bar adalah 10,77 mg ascorbic acid $\mathrm{g}^{-1}$, artinya setiap $1 \mathrm{~g}$ produk memiliki aktivitas antioksidan yang setara dengan $10,77 \mathrm{mg}$ asam askorbat. Kandungan antioksidan pada produk snack bar bee pollen masih rendah. Berdasarkan penelitian yang dilakukan oleh Marjan et al. (2016) suatu bahan makanan dapat diklaim sebagai makanan fungsional jika memiliki faktor penghambat radikal bebas sebesar $50 \%$. Kandungan antioksidan pada bee pollen memberikan pengaruh pada kandungan antioksidan snack bar. Kandungan antioksidan yang terkandung pada bee pollen bergantung pada jenis vegetasi, iklim dan lingkungan dari lebah (Campos et al., 2010).

\section{Daya terima bee pollen snack bar pada anak usia sekolah}

Hasil yang diperoleh dari uji organoleptik menggunakan facial hedonic scale pada 30 anak usia sekolah adalah $63 \%$ sangat suka, $33 \%$ suka dan $3 \%$ sangat tidak suka. Nilai rata-rata dari uji organoleptik snack bar pada anak usia sekolah adalah 4,5 yang berarti anak-anak menyukai rasa dari produk. Berdasarkan $\mathrm{Fu}$ et al. (2007) anak-anak cenderung menyukai makanan yang manis seperti cokelat dan permen, bee pollen snack bar menggunakan cokelat sebagai penambah rasa yang merupakan hal yang disukai oleh anak-anak. Hal ini membuktikan bahwa rasa asam yang merupakan rasa dominan asam dari bee pollen dapat diterima dengan baik oleh anak-anak.

Kandungan bee pollen berbeda dengan pollen atau serbuk sari dari tanaman, meskipun merupakan campuran dari banyak serbuk sari tanaman, namun kejadian alergi karena bee pollen masih jarang terjadi dan hingga kini masih menjadi perdebatan, sehingga konsumsi bee pollen cukup aman untuk dikonsumsi oleh anak-anak. Penelitian yang dilakukan oleh Basista et al. (2012) telah membuktikan bahwa kasus alergi bee pollen terhadap sangat jarang terjadi, hasil penelitian yang dilakukan pada petani lebah dan keluarganya menyatakan bahwa 
hanya 0,56\% kasus alergi yang terjadi pada 493 subjek penelitian. Konsumsi bee pollen tetap harus diperhatikan, mengingat bee pollen merupakan makanan yang tinggi protein, karena merupakan hasil fermentasi dari serbuk sari yang bercampur dengan saliva lebah yang tinggi kandungan protein (Basista et al., 2012), sehingga potensi alergi dapat terjadi pada seseorang yang sensitif terhadap makanan yang tinggi protein.

\section{KESIMPULAN}

Snack bar dengan penambahan bee pollen sebesar $10 \%$ merupakan formula terpilih berdasarkan rekomendasi konsumsi bee pollen per hari. Snack bar dengan penambahan $10 \%$ bee pollen merupakan produk selingan yang sangat baik untuk diberikan kepada anak usia sekolah karena memiliki kandungan gizi yang baik, dilengkapi juga oleh kandungan antioksidan dan asam amino. Snack bar mengandung kandungan kadar air sebesar 5,91\%, abu sebesar $1,72 \%$, protein sebesar $11,30 \%$, lemak sebesar $16,52 \%$ dan karbohidrat sebesar 64,52 \%. Aktivitas antioksidan dari snack bar adalah 10,77 mg ascorbic acid $\mathrm{g}^{-1}$, hal ini dapat diartikan bahwa $1 \mathrm{~g}$ produk dapat menghambat aktivitas radikal bebas setara dengan 10,77 g asam askorbat (vitamin C). Snack bar dapat diterima dengan baik oleh anak usia sekolah, 29 dari 30 siswa menyukai snack bar pada uji penerimaan produk.

\section{DAFTAR PUSTAKA}

[AOAC] Association of Official Analytical Chemist. 2006. Official Method of Analysis of Association of Official Analytical Chemist. Ed ke-16. AOAC Inc, Airlangton.

Aaron GJ, Lo NB, Hess SY, Guiro AT, Wade S, Ndiaye NF, Guinard JX, Brown KH. 2011. Acceptability of complementary foods and breads prepared from zinc-fortified cereal flours among young children and adults in Senegal. J Food Sci 76: 56-62. DOI: 10.1111/j.1750-3841. 2010.01909.x.

Attia YA, Abd Al-hamid AE, Ibrahim MS, Al-Harthi MA, Bovera F, Elnaggar AS. 2014. Productive performance, biochemical and hematological traits of broiler chickens supplemented with propolis, bee pollen, and mannan oligosaccharides continuously or intermittently. Livest Sci 164: 87-95. DOI: 10.1016/j.livsci.2014.03.005.

Basista K, Filipek B, Sodzawiczny K. 2012. Bee pollen allergy in polish beekeepers and their family. Dermatologi Alergologi 29: 343-347. DOI: 10.5114/pdia.2012.31486.
Beltrán-Navarro B, Matute $\mathrm{E}$, Vasques-Garibay $\mathrm{E}$, Zarabozo D. 2012. Effect of chronic iron deficiency on neuropsychological domains in infants. J Child Neurol 27: 297-303. DOI: 10.117 7/0883073811416867.

[BSN] Badan Standardisasi Nasional. 2011. SNI standar mutu cookies (SNI: No 01-2973-1992). http:/www.sisni.bsn.go.id [3 April 2018].

Campos MGR, Frigerio C, Lopes J, Bogdanov S. 2010. Review article: What is the future of beepollen?. J ApiProduct ApiMedical Sci 2: 131144. DOI: 10.3896/IBRA.4.02.4.01.

Candra AA, Setiawan B, Damanik R. 2013. Pengaruh pemberian makanan jajanan, pendidikan gizi, dan suplementasi terhadap status gizi, pengetahuan gizi, dan status anemia pada anak usia sekolah dasar. J Gizi Pangan 8: 103108. DOI: 10.25182/jgp.2013.8.2.103-108.

de Arruda VAS, Pereira AAS, Freitas AS, Barth OM, Almeida-Muradian LB. 2013. Dried bee pollen: B complex vitamin, physicochemical and botanical composition. J Food Comp Anal 29: 100-105. DOI: 10.1016/j.jfca.2012.11.004.

Estevinho LM, Rodrigues $S$, Pereira AP, Feás $X$ 2012. Portugese bee pollen: Palynologycal study, nutritional and microbiological evaluation. Int J Food Sci Tech 47: 429-435. DOI: 10.1111/ j.1365-2621.2011.02859.x.

Fatrcová-Šramková, Nôžková J, Máriássyová $M$, Kačániová M. 2016. Biologically active antimicrobial and antioxidant substances in the Helianthus annuus L. bee pollen. J Environ Sci Health B51: 176-181. DOI: 10.1080/03601234.2 015.1108811.

Fu M, Cheng L, Tu S, Pan W. 2007. Association between unhealthful eating patterns and unfavorable overall school performance in children.J Am Diet Assoc 107: 1935-1943. DOI: 10.1016/j. jada.2007.08.010.

Grosso G, Estruch R. 2015. Nut consumption and age-related disease. $\mathrm{J}$ maturitas 84: 11-16. DOI: 10.1016/j.maturitas.2015.10.014.

Husby I, Heitmann BI, Jensen KO. 2009. Meals and snack from child's perspective: The contribution of qualitative method to development of dietary intervention. Public Health Nutr 12: 739-747. DOI: $10.1017 /$ S1368980008003248.

Kustyawati ME, Susilawati, Tobing D, Trimaryanto. 2012. Profil asam lemak dan asam amino susu kambing segar dan terfermentasi. J Teknol Industri Pangan 23: 47-52.

Lachman J, Orsák $M$, Hejtmánková $A$, Kovářová $E$. 2010. Evaluation of antioxidant and total phenolic of selected Czech honey. LWT-Food Sci 
Technol 43: 52-58. DOI: 10.1016/j.Iwt.2009.06. 008.

Mah E, Schulz JA, Kaden VN, Lawless SL, Rotor J, Mantila LB, Liska DJ. 2017. Cashew consumption reduces total and LDL cholesterol: a randomized, crossover, controlled-feeding trial. Am J Clin Nutr 101: 1070-1078. DOI: 10.3945/ ajcn.116.150037.

Marjan AQ, Marliyati A, Ekayanti I. 2016. Pengembangan produk pangan dengan substitusi red palm oil sebagai alternatif pangan fungsional tinggi beta karoten. J Gizi Pangan 11: 91-98.

Nagai T, Inoue R, Suzuki N, Tanoue $\mathrm{Y}$, Kai N, Nagashima T. 2007. Antihypertensive activities of enzymatic hydrolysates from honeybee-collected pollen of Cistus ladaniferus. J Food Agric Environ 5: 86-89.

Pasricha SS, Flecknoe-Brown CS, Allen JK, Gibson RP, McMahon PL, Olynyk KJ. 2010a. Diagnosis and management of iron deficiency anaemia: $A$ clinical update. Med J Australia 193: 525-532. DOI: 10.5694/j.1326-5377.2010.tb04038.x.

Pasricha SR, Black J, Muthayya S, Shet A, Bhat V, Nagaraj S, Prashanth NS, Sudarshan H, Biggs BA, Shet AS. 2010b. Determinants of anemia among young children in Rural India. Pediatrics 126: 140-149. DOI: 10.1542/peds.2009-3108.

Prado EL, Dewey KG. 2014. Nutrition and brain development in early life. Nutr Rev 72: 267-284. DOI: $10.1111 /$ nure.12102.

Rachmayani N, Rahayu WP, Faridah DN, Syamsir E. 2017. Snack bar tinggi serat berbasi tepung ampas tahu (okara) dan tepung ubi ungu. J
Teknol Industri Pangan 28: 139-149. DOI: 10. 6066/jtip.2017.28.2.139.

Rzepecka-Stojko A, Stojko J, Kurek-Górecka A, Górecki M, Kabała-Dzik A, Kubina R, Moździerz A, Buszman E. 2015. Polyphenols from bee pollen: structure, absoption, metabolism and biological activity. Molecules 20: 21732-21749. DOI: 10.3390/molecules201219800.

Sakti B. 2015. Pengembangan Pasar Produk Sormeal Sebagai Pangan Fungsional Dan Komoditi Diversifikasi Karbohidrat [Skripsi]. Bogor: Fakultas Teknologi Pertanian, Institut Pertanian Bogor.

Sandjaja S, Budiman B, Harahap H, Ernawati $F$, Soekatri M, Widodo $Y$, Sumedi $E$, Rustan $F$, Sofia G, Syarief SN, Khouw I. 2013. Food consumption and nutritional and biochemical status of 0.5-12-year-old Indonesian children: the SEANUTS study. British J Nutr 110: 11-20 DOI: 10.1017/S0007114513002109.

Suani. 2012. Potensi sorgum sebagai bahan pangan fungsional. J IPTEK Tanaman Pangan 7: 58-66.

Winarno FG. 2008. Kimia Pangan dan Gizi. 28-31. PT Gramedia Pustaka Utama, Jakarta.

Yang K, Wu D, Ye X, Liu D, Chen J, Sun P. 2013. Characterization of chemical composition of bee pollen in China. J Agric Food Chem 61: 708-718. DOI: $10.1021 / \mathrm{j}\} 304056 \mathrm{~b}$.

Yasmin G, Madanijah S. 2010. Perilaku penjaja pangan jajanan anak sekolah terkait gizi dan keamanan pangan di Jakarta dan Sukabumi. J Gizi Pangan 5: 148-157. DOI: 10.25182/jgp. 2010.5.3.148-157. 